IRSTI 67.01 .93

\author{
$\underline{\text { Zh. Amangeldi }}{ }^{1}, \underline{\text { N. Bergeneva }}{ }^{2}, \underline{\text { A. Baibosyn }}{ }^{3}$ \\ 1,2,3 al-Farabi Kazakh National University, Almaty, Kazakhstan
}

\title{
INJURY RISKS IN CIVIL CONSTRUCTION
}

Annotation. The article discusses an overview of the causes of injuries in construction. Also the statistics of industrial accidents are occurred. The actual problems of ensuring labor safety and health protection of workers in the construction industry have been studied.

Keywords: labor safety, organization of civil construction, labor protection, industrial injuries, risks in construction site, occupational risk management.

Health and safety issues have always been a major concern in the construction industry. Construction has always been one of the most dangerous factors affecting human health and safety criteria, especially in developing countries. Despite government programs and company-wide measures, the number of construction accidents and risks remain alarmingly high [1]. In developing countries, safety regulations generally do not exist; even if they do, regulation in this regard is poorly represented. Unfortunately, some sectors of the civil construction industry are particularly suffering from inadequate measures of industrial safety. Any existing types of occupational disease are fragmented and misapplied, thus making construction sites even more dangerous. Therefore, it can even be argued that the relevant standards are outdated and irrelevant in the daily practice of construction $[1,2]$.

At the organizations of the construction complex, almost $30 \%$ of the total number of employees were involved in hard work and work with harmful working conditions. Moreover, over $9 \%$ work in conditions that do not meet the conditions of sanitary and hygienic requirements: with a high concentration of dust and gas pollution of the environment, unacceptable level of noise, vibration, low illumination of the workplace, etc. As a result of unsatisfactory working conditions at construcion sites and in workshops at enterprises, there is an increase in injuries and occupational diseases.

According to observations, it is known that industrial injuries in many cases are associated with organizational, technical and medical reasons: poor organization of work, violation of labor and production discipline, insufficient qualifications and training of workers in labor protection, a high degree of deterioration of construction machinery and equipment, as well as lack of effective means of collective and individual protection of workers.

Top 4 massive violations leading to injury, and in the worst case, to death:

Lack of personal protective equipment for workers at a construction site;

Lack of temporary fences;

Cases of workers falling from a height;

Absence of struts at the construction site [3].

The most common violation is the lack of personal protective equipment for workers at a construction site. These include, in particular, special boots with a metal 
insole and a cape, protective vests and helmets, etc. As a rule, insufficient equipment among workers is associated with the contractor's economy or poor professional training of the specialists themselves.

The next violation is the lack of fences. It is not only about the fence around the construction site, but also about the fences inside the building under construction.

In the ceilings of each floor, there are a large number of openings for elevator shafts and communications. If these holes are not covered, then the worker can fall into them. According to statistics, falling from a height is the most common accident during construction, and it is caused precisely by negligence of the construction of fences. In this case, the construction manager may even bear criminal responsibility. Cases of workers falling from a height are unfortunately quite common. This is either due to their carelessness and incaution, or due to the fact that the high-rise parts of the building were not properly fenced. In addition, people stumble when carrying out facade work on the assembly scaffolding. In many cases, they neglect insurance (safety belt) for supposedly greater mobility.

Organizational works also sometimes may miss to use struts - elements that prevent the fall of reinforced concrete slabs during installation. In some cases, this struts may not be available at all on the construction site, which is extremely dangerous.

The leading factors of injury, incl. with a lethal outcome, are the negative effects of operating equipment and mechanisms, electric shock.

In modern economic conditions, the main task of the state in the field of labor protection is to create conditions that ensure the preservation of the life and health of citizens in the process of labor activity. Therefore, the state, first of all, takes into account and protects the rights and legitimate interests of employees. In this regard, an analysis of the dynamics of industrial injuries for 2015-2019 was carried out, which was compiled on the basis of statistical data from the State Labor Inspectorate of the Ministry of Labor and Social Protection of the Population of the Republic of Kazakhstan and the Bureau of National Statistics of the Agency for Strategic Planning and Reforms of the Republic of Kazakhstan [4].

Thus, the analysis of industrial injuries showed that at the end of 2019, the number of injured at enterprises amounted to 1,430 people. Compared to $2018(1,568$ people), this indicator decreased by $8.8 \%$. It should be noted that in 2019 (1,430 people) there was a minimum number of people injured in accidents related to work over the past five years (Fig. 1), respectively, the indicator decreased by $17.0 \%$ compared to 2015 (1,723 people) [4].

Work on construction sites is carried out with significant violations, when safety is brought to the detriment of savings and acceleration of the construction process, i.e. attempts to increase the investment attractiveness and efficiency of the company at the expense of the safety of its employees [5]. Data on this problem are given below (Fig. 2). 


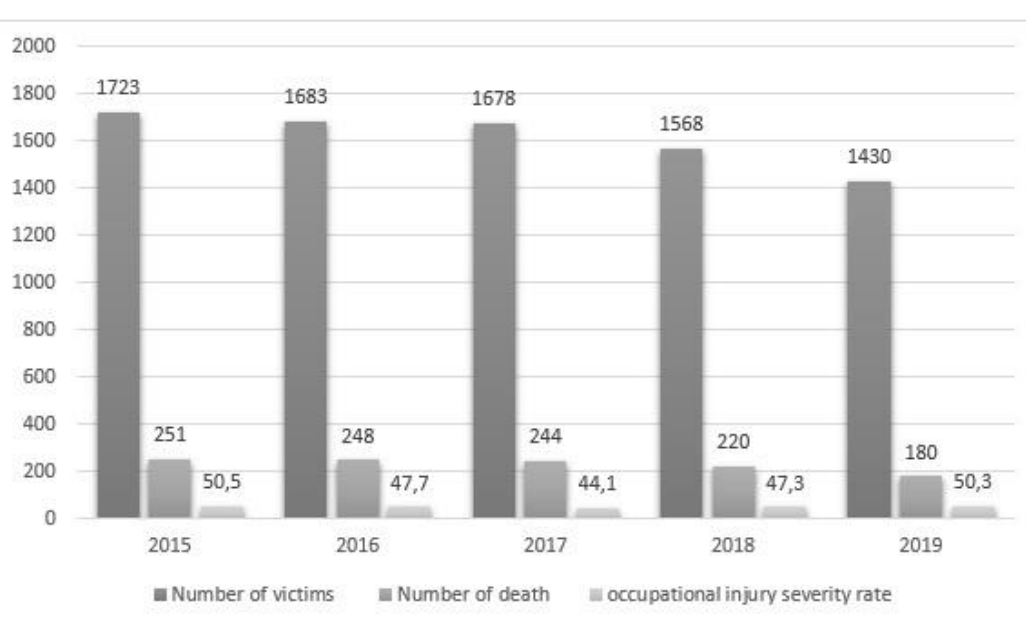

Figure 1 - Statistics of accident for 2015-2019

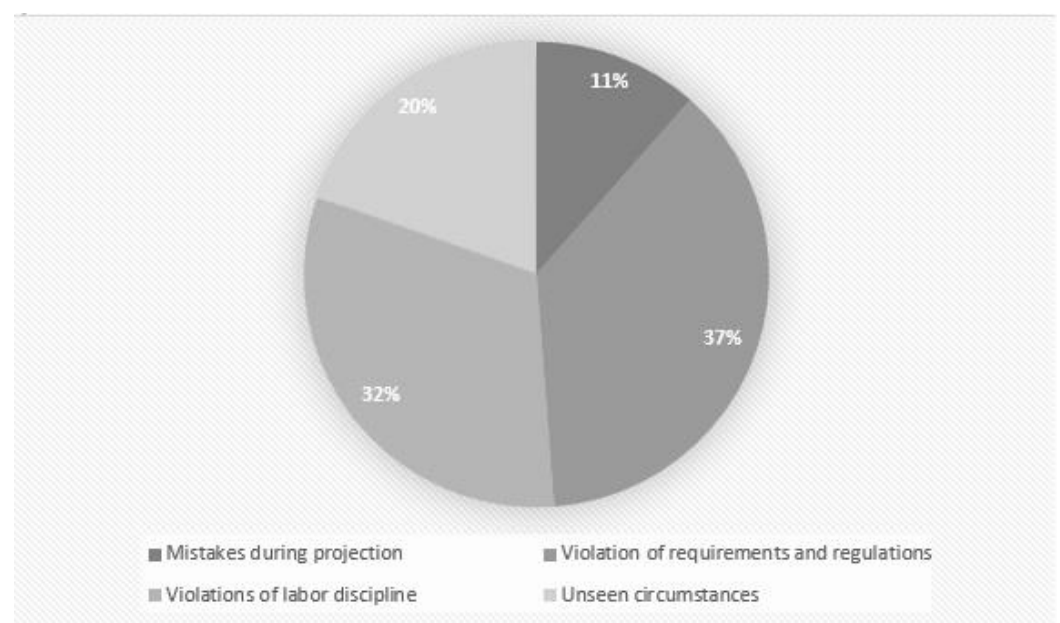

Figure 2 - Correlation of violations in construction

The main measures for the prevention of industrial injuries are associated with the prevention of three main types of causes of injuries: 1) technical, 2) organizational, and 3) personal [6].

1. Technical causes of industrial accidents are eliminated by improving technological processes, replacing equipment that has design flaws and high wear and tear, constant monitoring (diagnostics) of the technical condition of equipment, buildings and structures, tools and means of collective and individual protection.

Effective and purely technical safety measures are engineering measures to protect people from sources of harmful effects by isolating hazardous elements, as well as installing barriers between workers and potential sources of injury. These include (but are not limited to) automation, remote control, the use of auxiliary equipment and automatic protection.

Normalization of working conditions also plays an important role: high-quality atmosphere, good lighting, absence of noise and vibration, normal microclimate, etc.

2. Organizational causes of industrial accidents are eliminated by introducing a corporate OSH management system. Organizational safety measures include, among 
other things, protecting workers from sources of hazardous and (or) harmful effects by providing workers with personal protective equipment and rational temporary organization of the work process.

An important role in improving labor protection is played by product quality management, which inevitably eliminates shortcomings in the organization of workplaces and violations of technological regulations, rules and regulations for transportation, warehousing and storage of materials and products, scheduled preventive maintenance of equipment, vehicles and tools.

3. Personal (psychophysiological) causes of accidents at work can be eliminated through the correct selection of personnel, as well as with constant training, instruction and education, stimulating the safe behavior of workers. Since it is not possible to completely eliminate hazards through technical and organizational measures, the safety of an employee is often determined only by his behavior.

In order for workers to have the necessary understanding of all types of risks, potential hazards and dangerous items of equipment that are present in the workplace, and to know when they are exposed to one or another hazard and what the consequences of their actions may be, appropriate education, training (training and training) and work experience.

Although for each workplace (or type of work) under the normal organization of labor protection there are instructions on labor protection, often the requirements set out in them are forgotten by workers, especially those of relatively low qualifications. A much better role can and should be played by various posters, warning signals, markings and colors, safety signs.

Since absolute safety at work, in principle, does not exist and cannot exist, then each employee must be ready to actively counter hazards and to provide first aid to the injured.

The actions of workers in an emergency and immediately after the occurrence of an accident must be thought out and organized in advance. At the same time, the appropriate signs and information placed in the necessary places (designation of emergency exits, fire extinguishers, the location of first aid stations, showers, eyewash fountains or blocking devices) serve as extremely clear instructions for taking quick adequate measures [7].

\section{Conclusion}

Considering occupational injuries in enterprises, one can come to the conclusion that there is a certain connection between the state of the human body and an accident.

The prevention of industrial injuries has been and remains a complex problem that requires the increased attention of specialists in various fields.

When developing a plan of preventive measures to prevent injuries, an important aspect is not only a list of them, but also ranking, that is, determining the degree of importance of the contribution of each measure to the state of working conditions. 


\title{
References:
}

1. Badaguev B.T. (2019) Industrial accidents and occupational diseases: investigation, registration [Neschastnyie sluchai na proizvodstve i professionalnyie zabolevaniya: rassledovanie, oformlenie]. Moscow, Russia. (in Russian)

2. Samsonov AYu (2018) Assessment of the current state of industrial accidents and occupational diseases in Russia [Otsenka sovremennogo sostoyaniya proizvodstvennogo travmatizma i professionalnoy zabolevaemosti v Rossii] №2. (in Russian)

3. Manzhilevskaya S.E., Shilov A.V., Chubarova K.V. (2015) [Organizatsionnyiy inzhiniring] №3 SN RK 1.03-05-2011 Labor protection and safety in construction [Ohrana truda i tehnika bezopasnosti $v$ stroitelstve]. Republic of Kazakhstan, 2011. (in Russian)

4. Ryibnova E.I. (2017) Safety in construction [Bezopasnost v stroitelstve] (in Russian)

5. Roik VD (2017). Management of working conditions and labor protection: Textbook. [Upravlenie usloviyami i ohranoy truda: Uchebnoe posobie.] Moscow, Russia. (in Russian)

6. Tsaplin V.V., Kirsi T, Taru P. (2017) Formation of a safe behavioral model of workers is a real need for modern production processes [Formirovanie bezopasnoy povedencheskoy modeli rabotnikov - realnaya potrebnost sovremennyih proizvodstvennyih protsessov] (in Russian)

\section{$\underline{\text { Ж. Амангелді }}{ }^{1}, \underline{\text { Н. Бергенова²}}, \underline{\text { А. Байбосын }}$}

1,2,3 әл-Фараби атындағы Қазақ Ұлттық университеті, Алматы қ., Қазақстан республикасы al-Farabi Kazakh National University, Almaty, Kazakhstan

\section{ҚҰРЫЛЫСТАҒЫ ЖАРАҚАТ АЛУ ТӘУЕКЕЛДЕРІ}

Андатпа. Мақ̧алада құрыльставы жарақ̧аттардың себептеріне шолу қ̧арастырылады. Сондай-ақ өндірістік апаттардың статистикасы келтірілген. Кұрылыс саласындагы жұмысшылардың еңбек қ̧ауіпсіздігі мен денсаулывын қ̧ордаудың өзекті мәселелері зерттелді.

Түйін сөздер: еңббек құауіпсіздігі, азаматтық құрылысты ұйымдастыру, еңббекті

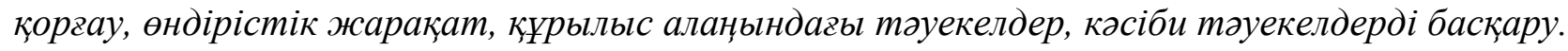

\author{
$\underline{\text { Ж. Амангелди }}{ }^{1}, \underline{\text { Н. Бергенова }}{ }^{2}, \underline{\text { А. Байбосын }}$ \\ 1,2,3 аль-Farabi Kazakh National University, Almaty, Kazakhstan \\ РИСКИ ТРАВМИРОВАНИЯ В СТРОИТЕЛЬСТВЕ
}

\begin{abstract}
Аннотация. В статье рассматривается обзор причин травм в строительстве. Также ведется статистика несчастных случаев на производстве. Исследованы актуальные проблемы обеспечения безопасности труда и охраны здоровья рабочих в строительной отрасли.

Ключевые слова: охрана труда, организация гражданского строительства, охрана труда, производственный травматизм, риски на строительной площадке, управление профессиональными рисками.
\end{abstract}

